\title{
Decomposition of Regional Development Shifts
}

\author{
R.R. Akhunov, A.V. Yangirov
}

Abstract:Subject. No breakthrough in the economic development of the Russian Federation could be achieved without the maximum utilisation of the inner regional potential. This implies high relevance of studies concerning the aspects of influence produced by internal and external factors on regional development, as well as analyses of the existing conditions at the macroeconomic level that support or hinder the engagement of inner regional reserves and opportunities in the regions' socioeconomic development. This would make the basis for a more comprehensive view of the regional system and its inherent properties, helping to identify ways to manage regional development.

Objectives. Analysis and decomposition of developmental shifts in the Russian regions and their classification based on internal and external influences.

Methods. The primary research method is the shift-share analysis method. The methods of logical and statistical analysis, particularly, correlation analysis, are also used.

Results. The driver effects of shifts are calculated at the national, industry, and regional levels for 80 regions of the Russian Federation and the period comprising two time points, 2012 and 2017. The regional and industry effects are analysed by the types of economic activities. It is established that, firstly, the regional effect is negative for most regions and, secondly, the industry effect (in combination with the national effect) acts to smooth out the negative regional effect.

Conclusions. A conclusion is made that positive shifts can be achieved both in strong and weak regional economies. Generally, the shifts in Russian regions are mostly influenced specifically by the internal regional conditions, which are mostly adverse, suggesting high importance of regional effects. The research highlights the significance of industry policies at the federal level, primarily in economic activities such as agriculture and manufacturing, and the need for improvement of regional policies implemented at the federal level to raise the number of self-developing regions.

Keywords: region, regional development, shift-share analysis method, national effect, industry effect, regional effect.

\section{INTRODUCTION}

$\mathrm{R}$ Russia's current objectives to sustain breakthrough socioeconomic development require more focus on regional problems and governance decision-making at this level [1, 2]. However, no systemic vision has yet emerged as to how

Revised Manuscript Received on December 30, 2019.

* Correspondence Author

R.R. Akhunov*, Ufa Federal Research Center of the Russian Academy of Sciences, Ufa, Russia.

A.V. Yangirov, Ufa Federal Research Center of the Russian Academy of Sciences, Ufa, Russia.

(C) The Authors. Published by Blue Eyes Intelligence Engineering and Sciences Publication (BEIESP). This is an open access article under the CC BY-NC-ND license (http://creativecommons.org/licenses/by-nc-nd/4.0/) regional development problems might be addressed [3]. We believe that the existing federal model of regional governance does not fit the challenges of such breakthrough development. The imperfection of the current spatial development outlook in the Russian Federation calls for a revision of the model's traditional priorities reflecting the focus on leveling-off regional socioeconomic development in a top-down approach centred on paternalism and centralisation. Therefore, one of the new priorities could be the so-called endogenous regional development and, on the other hand, ensuring a stable macro environment at the national level. The purpose of this paper is the analysis and decomposition of developmental shifts in the Russian regions and their classification based on internal and external influences aimed to identify the regions with the most visible endogenous development factors.

\section{LITERATURE REVIEW}

The current objectives of regional socioeconomic development include the need to ensure meaningful positive shifts in different areas of the economy. There are various drivers to invoke such shifts, associated with a range of various socioeconomic factors classified by Iu.N. Minaev [4], N.V. Neveikina [5], V.Z. Petrosyants, S.V. Dokholyan [6], and others. Of all the factors in play, this paper focuses on those identified by N.V. Neveikina according to the so-called spatiality criterion [5, p. 79]. Specifically, to what extent the change is invoked by external and systemic factors for the region, over which it can only have limited control, and to what extent its inner regional, internal factors come into play, defining the region's strength and capability of development notwithstanding the external effects. Thus, the potential of self-development can be determined, as well as the degree of the region's reliance on external conditions.

Recognising a considerable number of determinants in external factors, this paper focuses on the most significant two of them, namely: national conditions, which, in turn, are influenced by global conditions, and industry factors related to the dynamics of economic activity types at the national level. National conditions reflect the overall state of the national economy and activity levels and can be expressed by trends in various macro indicators, such as the rates of GDP, employment, prices, interest rates, and private income growth in the country. To some extent, industry factors reflect the so-called market conditions defining the situation in specific markets of goods and services [7].

The analysed internal regional factors can be referred to as the factors of self-development and associated with the category of "regional self-development" in economic literature, specifically described by E.M. 
Bukhvald [8], I.S. Mezhov, I.N. Sycheva, and E.S. Permyakova [9], A.I. Tatarkin and D.A. Tatarkin [10], V.S. Fedolyak [11], and I.N. Shvetsova and T.A. Naidenova [12]. As a result, these factors provide certain internal self-sufficiency of regional development and relative autonomy with regard to national factors. However, as can be seen further in this paper, such factors of self-development can be not only positive but also negative,

which points at both internal objective reasons and certain governance inefficiencies in a particular region.

\section{PROPOSED METHODOLOGY}

\section{A. General description}

The basic research method is the so-called shift-share analysis method. It was first introduced in 1960 by Perloff, Dun, Lampard, and Muth [13]. More descriptions of the method can be found further in works by Berzeg [14], Brown [15], Esteban-Marquillas [16], Floyd and Sirmans [17], Herzog and Olsen [18], Houston [19], James and Hughes [20], Lausen [21], Stevens and Moore [22], and Zimmerman [23]. They approach shift-share analysis as one of the methods to analyse regional development and attribute proportions of regional growth to national economic growth factors and the region's unique growth factors. Consequently, this method attempts to isolate the economic components of growth at the national level from its regional components. In the classic model, the calculations are based on employment figures for two periods. The model assumes that employment growth in a region over a certain period can be attributed to three reasons: national growth, nation industry shifts, and internal regional shifts. The regional effect is the most interesting and represents the unique advantages of the region. It is recognised where a certain industry in a region outpaces both the overall national growth and same-industry growth rate on the national scale. Such outperformance may imply a unique competitive advantage for such industry in the region. The effects may be due to factors such as economic geography, regional governance, demographics, labour profile, natural resources, etc.

This study focused on the analysis of annual average employment for 2012 and 2017 for 80 subject regions, which reflects the accession of autonomous areas (the Nenets, Khanty-Mansi, and Yamalo-Nenets Autonomous Areas) within larger regions (the Arkhangelsk and Tymen regions) and exclusion of the Republic of Crimea and Sevastopol due to the lack of long-term statistics in the retrospective.

\section{B. Algorithm}

The model is formalised as follows:

$\Delta R_{i}=R_{i, t}-R_{i, t-1}=N S_{i}+I M_{i}+R S_{i}$

where $\Delta R_{i}$ is the absolute change at the regional level for i-th economic activity type; $R_{i, t}$ is the absolute value at the regional level for i-th economic activity type in period t; $R_{i, t-1}$ is the absolute value at the regional level for $\mathrm{i}$-th economic activity type in period $\mathrm{t}-1 ; N S_{i}$ is the absolute national effect influencing the change for i-th economic activity type; $I M_{i}$ is the absolute industry effect influencing the change for i-th economic activity type; $R S_{i}$ is the absolute regional effect influencing the change for $\mathrm{i}$-th economic activity type.
National effect:

$$
N S_{i}=R_{i, t-1} \cdot \frac{E_{t}-E_{t-1}}{E_{t-1}}
$$

where $E_{t}$ is the absolute value of the national indicator for period $\mathrm{t} ; E_{t-1}$ is the absolute value of the national indicator for period $\mathrm{t}-1$.

Regional effect:

$I M_{i}=R_{i, t-1} \cdot\left(\frac{E_{i, t}-E_{i, t-1}}{E_{i, t-1}}-\frac{E_{t}-E_{t-1}}{E_{t-1}}\right)$

where $E_{i, t}$ is the absolute value of the national indicator for i-th economic activity type for period t; $E_{i, t-1}$ is the absolute value of the national indicator for i-th economic activity type for period $\mathrm{t}-1$.

Regional effect:

$R S_{i}=R_{i, t-1} \cdot\left(\frac{e_{i, t}-e_{i, t-1}}{e_{i, t-1}}-\frac{E_{i, t}-E_{i, t-1}}{E_{i, t-1}}\right)$

where $e_{i, t}$ is the absolute value of the indicator at the regional level for i-th economic activity type for period $t$; $e_{i, t-1}$ is the absolute value of the indicator at the regional level for i-th economic activity type for period $\mathrm{t}-1$.

The above equations measure the absolute effects, which may not always allow appropriately comparing regions. Therefore, the described effects can be rendered as relative measures:

$\Delta r_{i}=n s_{i}+i m_{i}+r s_{i}$

$n s_{i}=\left(\frac{E_{t}-E_{t-1}}{E_{t-1}}\right) \cdot 100 \%$

$\operatorname{im}_{i}=\left(\frac{E_{i, t}-E_{i, t-1}}{E_{i, t-1}}-\frac{E_{t}-E_{t-1}}{E_{t-1}}\right) \cdot 100 \%$

$r s_{i}=\left(\frac{e_{i, t}-e_{i, t-1}}{e_{i, t-1}}-\frac{E_{i, t}-E_{i, t-1}}{E_{i, t-1}}\right) \cdot 100 \%$

where $\Delta r_{i}$ is the relative change (growth rate) of the indicator at the regional level for i-th economic activity type, $\% ; n s_{i}$ is the relative national effect (growth rate due to the national effect) in the change of the indicator for i-th economic activity type, $\% ; i m_{i}$ is the relative industry effect (growth rate due to the industry effect) in the change of the indicator for i-th economic activity type, $\% ; r s_{i}$ is the relative regional effect (growth rate due to the regional effect) in the change of the indicator for i-th economic activity type, \%.

The following equations can be used to calculate the effects for all types of economic activity (for the economy overall):

$$
\begin{aligned}
& \Delta r=n s+i m+i m \\
& n s=\left(\frac{\sum_{i=1}^{n} N S_{i}}{e_{t-1}}\right) \cdot 100 \% \\
& i m=\left(\frac{\sum_{i=1}^{n} I M_{i}}{e_{t-1}}\right) \cdot 100 \%
\end{aligned}
$$


$r s=\left(\frac{\sum_{i=1}^{n} R S_{i}}{e_{t-1}}\right) \cdot 100 \%$

where $\Delta r$ is the relative change (growth rate) of the indicator at the regional level for all economic activity types (across the economy), \%; $n s$ is the relative national effect (growth rate due to the national effect) in the change of the indicator for all economic activity types (across the economy), \%; im is the relative industry effect (growth rate due to the industry effect) in the change of the indicator for all economic activity types (across the economy), \%; $r s$ is the relative regional effect (growth rate due to the regional effect) in the change of the indicator for all economic activity types (across the economy), \%; $e_{t-1}$ is the absolute change of the indicator at the regional level for all economic activity types (across the economy) in period $\mathrm{t}-1$.

\section{RESULT ANALYSIS}

Only 29 of the 80 analysed subject regions of the Russian Federation registered growing or flat annual average employment for the period of 2012 and 2017. The national effect (ns) measured at 5.7\%; the industry and regional effects generally for the respective economies are laid out in Table 1.

Table 1: Shift-share analysis calculations for subject regions of the Russia Federation with growing or flat annual average employment for 2012 and 2017

\begin{tabular}{|c|c|c|c|c|c|c|}
\hline Region & $\begin{array}{l}\text { Industryeffect }(\mathrm{im}) \text {, } \\
\%\end{array}$ & Region'srankbyvalueim & $\begin{array}{l}\text { Regionaleffect }(r s) \text {, } \\
\%\end{array}$ & Region'srankbyvaluers & $\begin{array}{l}\text { Overallchange } \Delta r \text {, } \\
\%\end{array}$ & \begin{tabular}{|c} 
Region's rank by \\
per capita GRP \\
for 2017 \\
\end{tabular} \\
\hline Republic of Ingushetia & 9.9 & 2 & 139.5 & 1 & 155.2 & 80 \\
\hline Chechen Republic & 3.2 & 13 & 47.8 & 2 & 56.7 & 79 \\
\hline Moscow & -1.2 & 64 & 28.4 & 3 & 32.9 & 4 \\
\hline Saint Petersburg & -1.5 & 68 & 21.7 & 4 & 25.9 & 7 \\
\hline $\begin{array}{l}\text { Kabardino-Balkarian } \\
\text { Republic }\end{array}$ & 0.2 & 47 & 11.9 & 6 & 17.7 & 78 \\
\hline Moscow Region & -1.7 & 71 & 13.6 & 5 & 17.6 & 15 \\
\hline Tyumen Region & 3.1 & 14 & 4.6 & 11 & 13.4 & 1 \\
\hline Krasnodar Territory & -0.3 & 54 & 6.2 & 8 & 11.6 & 34 \\
\hline Republic of Daghestan & -1.3 & 66 & 6.8 & 7 & 11.2 & 73 \\
\hline Astrakhan Region & 0.5 & 45 & 4.0 & 12 & 10.1 & 28 \\
\hline Samara Region & -0.6 & 58 & 4.8 & 10 & 9.9 & 25 \\
\hline Belgorod Region & -2.8 & 76 & 5.3 & 9 & 8.2 & 16 \\
\hline Republic of Tatarstan & -0.4 & 56 & 1.5 & 13 & 6.8 & 13 \\
\hline Leningrad Region & -1.6 & 69 & 1.4 & 14 & 5.6 & 14 \\
\hline Tver Region & 2.5 & 20 & -3.1 & 20 & 5.1 & 51 \\
\hline Voronezh Region & -1.9 & 73 & 0.4 & 15 & 4.2 & 40 \\
\hline Lipetsk Region & 1.3 & 32 & -2.9 & 18 & 4.1 & 23 \\
\hline Chelyabinsk Region & 0.1 & 48 & -2.2 & 17 & 3.6 & 38 \\
\hline Kaluga Region & -0.7 & 61 & -1.9 & 16 & 3.1 & 29 \\
\hline $\begin{array}{l}\text { Chukotka Autonomous } \\
\text { Area }\end{array}$ & 10.7 & 1 & -13.3 & 51 & 3.1 & 3 \\
\hline Rostov Region & -0.3 & 53 & -3.0 & 19 & 2.4 & 48 \\
\hline $\begin{array}{l}\text { Republic of } \\
\text { (Yakutia) }\end{array}$ & 2.6 & 19 & -6.4 & 28 & 1.9 & 6 \\
\hline Republic of Mordovia & -0.5 & 57 & -3.3 & 21 & 1.9 & 59 \\
\hline Ryazan Region & 0.9 & 42 & -4.8 & 22 & 1.8 & 47 \\
\hline Sverdlovsk Region & 1.0 & 41 & -5.4 & 23 & 1.2 & 19 \\
\hline Tomsk Region & 0.8 & 43 & -6.1 & 25 & 0.3 & 20 \\
\hline
\end{tabular}

Source:calculated from Rosstat* data on annual average employment [24] (*Russian Federal State Statistics Service)

It is established that positive shifts in a region are not necessarily due to its high economic development profile, as confirmed by the calculated correlation coefficient across all regions between $\Delta r$ and per capita GRP for 2017, which only equals 0.03. The same is true for the regional effect: the correlation between rs with per capita GRP for the same year equalled minus 0.03 . This means that significant shifts can be achieved by even the weakest regions and the leaders by the indicator $\Delta r$ are the Republic of Ingushetia, the Chechen Republic, the Republic of Daghestan, and the Kabardino-Balkarian Republic. The first two also register the highest regional effects $(r s)$. Simultaneously, the leaders by $\Delta r$ and $r s$ also include major regions such as Moscow, Saint
Petersburg, the Moscow Region, the Tyumen Region, the Krasnodar Area, and others.

Notably, the regional effect is highly visible only for the first 12 regions with the highest shift levels, while it becomes much lower or even turns negative for the lower ranks. Further, 13 among the 29 analysed regions register inhibiting regional effects.

Consider next the regions characterised by the biggest negative shifts (Table 2). 
Table 2:Shift-share analysis calculations for subject regions of the Russia Federation with the biggest declines in annual average employment for 2012 and 2017.

\begin{tabular}{|c|c|c|c|c|c|c|}
\hline Region & $\begin{array}{l}\text { Industryeffect } \\
(\mathrm{im}), \%\end{array}$ & Region'srankbyvalueim & $\begin{array}{l}\text { Regionaleffect }(r s), \\
\%\end{array}$ & Region'srankbyvaluers & $\begin{array}{l}\text { Overallchange } \Delta r \text {, } \\
\%\end{array}$ & $\begin{array}{l}\text { Region's rank by per } \\
\text { capita GRP for } 2017 \\
\end{array}$ \\
\hline Perm Territory & 0.03 & 50 & -16.1 & 65 & -10.3 & 21 \\
\hline Kursk Region & -0.7 & 62 & -15.4 & 61 & -10.4 & 42 \\
\hline Republic of Karelia & 3.5 & 9 & -19.7 & 75 & -10.4 & 32 \\
\hline Kamchatka Territory & 4.4 & 8 & -21.0 & 76 & -10.9 & 11 \\
\hline Kurgan Region & 1.0 & 40 & -18.3 & 72 & -11.6 & 67 \\
\hline Murmansk Region & 6.2 & 4 & -25.1 & 80 & -13.2 & 12 \\
\hline Jewish Autonomous Region & 4.8 & 7 & -24.9 & 79 & -14.4 & 46 \\
\hline Pskov Region & 1.2 & 36 & -22.3 & 77 & -15.4 & 66 \\
\hline Orel Region & -0.3 & 55 & -23.7 & 78 & -18.4 & 54 \\
\hline
\end{tabular}

Source: calculated from Rosstat* data on annual average employment [24] (*Russian Federal State Statistics Service)

In this respect, we believe that maximising regional effects would be a debatable issue, as it may cause increasing regional autonomies. Strengthening national and industry effects may well be more efficient.

As with Table 1, the ranks in Table 2 also include both regions with high per capita GRP levels (the Kamchatka Territory, the Magadan Region) and weaker regions (such as the Kurgan and Pskov Regions). There is also a visible and strong link between overall negative shifts and negative regional effects, which are though smoothened out by the national and industry effects (the latter has contributed to the neutralisation of negative shifts for six out of ten analysed outsider regions). It is particularly true for the Republic of Karelia, the Kamchatka Territory, the Murmansk Region, and the Jewish Autonomous Region.

The research comprised the analysis of regional and industry effects by the industry. It is established that regional effects are most driven by shifts in agriculture, hunting, forestry, and fishery, with a clear prevalence of agriculture (the correlation of these types of economic activity with the overall regional effect is 0.92$)$, manufacturing (0.92 as well), wholesale and retail, car, motorcycle and individual and household appliances repair (0.90), hotels and restaurants (0.86), transportation and communications (0.84), construction $(0,84)$, healthcare and social services $(0.81)$, and education (0.73). These types of economic activity can be identified as the priorities of regional development with a view to maximising the regional effect. It turns out that mining produces the lowest effect $(0.21)$, which is consistent with the fact that this type of activity is most dependent on national and global conditions.

The positive industry effect registers the biggest influences in other activity types (including culture, sports, activities of non-government organisations, etc.) (+63.8\%), communications $(+57.7 \%)$, hotels and restaurants $(+27.2 \%)$, transportation $(+17.4 \%)$, power, gas, and water production and distribution (+16.4\%), construction (+6.3\%), and wholesale and retail, car, motorcycle and individual and household appliances repair (+5.6\%). Other types of economic activity show negative effects, particularly visible in agriculture, hunting, forestry, and fishery (-28.9\%) and real estate transactions, rent, and services $(-71.8 \%)$.

The analysis of regional effects found the following (Figure 1).

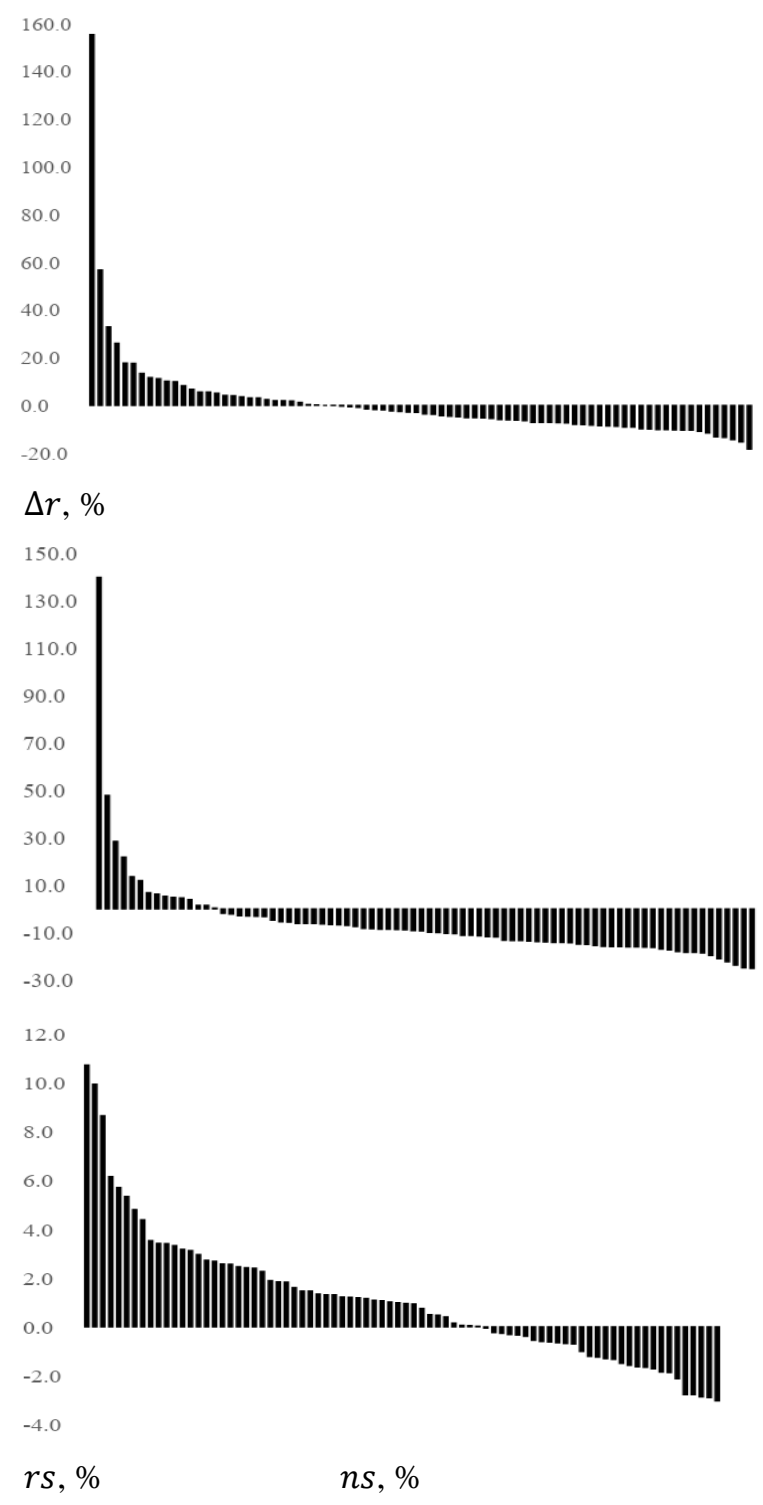

Fig. 1: Distribution of values of overall shifts $(\Delta \mathbf{r})$, regional effects (rs), and industry effects (ns) for Russian regions.

The biggest influences on overall regional shifts proved to be regional effects; the figure shows that their distribution profiles are quite similar. It is also confirmed by the coefficient of correlation between $\Delta r$ and $r s$ equal to 0.99 . 
However, the point of change of sign from positive to negative for overall shifts lies to the right from a similar point for regional effects. This means that, firstly, the regional effect is negative in most regions and, secondly, the industry effect (together with the national effect) contributes to smoothening out the negative regional effect. Besides, a comparison of the regional distribution of regional and industry effects showed that the strength of both the positive and negative industry effects is considerably lower than that of the regional effects: the average positive growth due to the

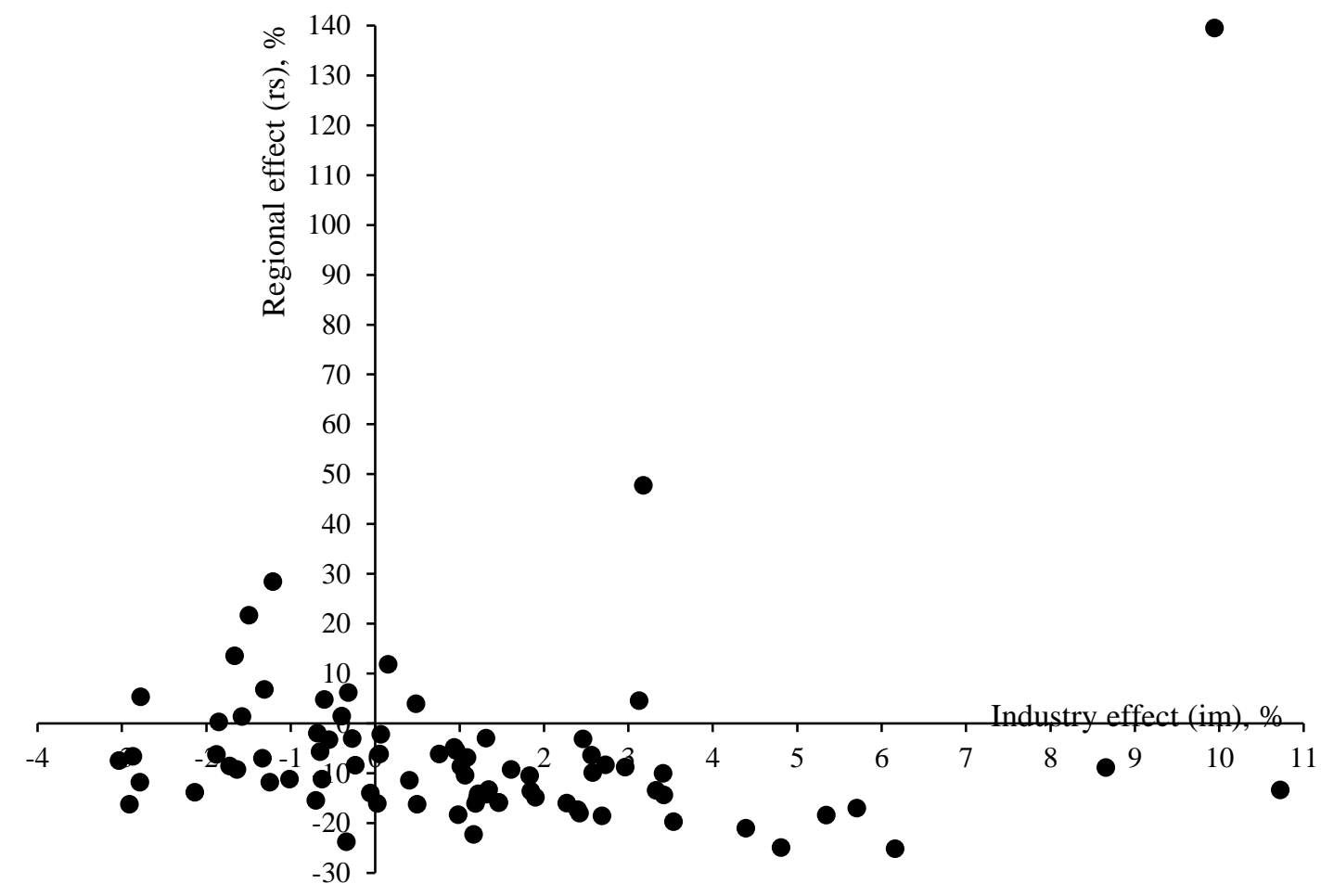

Fig. 2: Distribution of Russian regions in the axes of regional effects ( $r s)$ and industry effects (ns).

One of the groups would include a majority of regions (45 out of the total 80) falling within the area of the positive industry and negative regional effects, which is also a confirmation of the compensatory influence of the positive industry effect in the regions with negative regional effects. Another group would consist of 10 regions registering a compensatory influence of the positive regional effect over the negative industry effect. Yet another group would be the 20 regions with coinciding negative industry and regional effects. Finally, the smallest group would comprise five regions with positive industry and regional effects.

\section{CONCLUSION}

The findings of the research are as follows:

- the need to uncover inner resources of regional development promotes the relevance of analysing the shifts depending on the strength and direction of the inherent regional factors and their relation to the national and industry factors;

- the shift-share analysis is one of the methods to decompose the shifts in a region into three components, specifically, national conditions, industry growth rates at the national economic level, inner regional shifts. According to the method, if an industry's regional development outpaces regional effect is almost $20 \%$ vs. $2.5 \%$ due to the industry effect; the similar average negative growth due to the regional effect reached minus $12 \%$ vs. only minus $1.3 \%$ due to the industry effect.

Figure 2 allows producing a four-group classification of Russian regions depending on the direction of the industry and regional effects.

the rate of same-industry development at the national level and the overall national growth, it suggests the industry registers stronger competitive effects due to inner regional conditions;

- an analysis of shifts in Russian regions has shown that positive change can be achieved both in strong and weak regional economies. In general, the overall shifts in Russian regions have been mostly influenced by the inner regional conditions (the regional effect). Positive regional effects are only significant for a fraction of regions, while it is in most cases negative, which, as we believe, may, among other indications, point at certain governance inefficiencies in a particular region and systemic problems in the field.

- both positive and negative regional effects are mostly influenced by shifts in agriculture and manufacturing;

- industry effects at the national level show the biggest positive influence on Russian regional development in the so-called "other types of activities" (culture, sports, etc.) and communications, while the most significant negative influence shows in agriculture and real estate transactions;

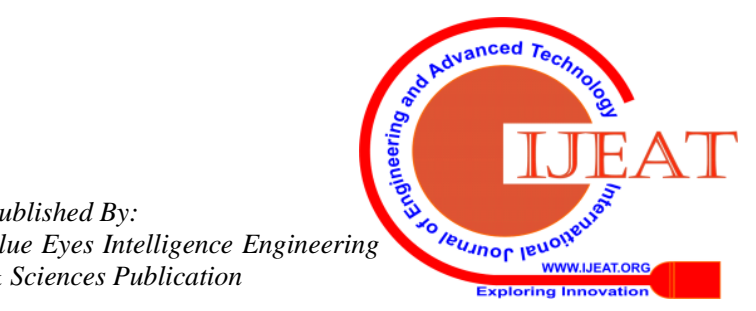


- regional effects emerge on a considerably wider scale compared to industry and national effects. However, it has been established that the latter produce smoothening (compensatory) influences on the negative regional effects for a majority of Russian regions.

The findings point at the need to improve 1) industry policies at the federal level to ensure positive industry effects, primarily in economic activities such as agriculture and manufacturing and 2) regional policies to increase the number of regions benefiting from positive regional effects and raising governance efficiency standards in them.

\section{ACKNOWLEDGMENT}

The paper was prepared under the research project in accordance with the public assignment of the Ministry of Science and Higher Education of the Russian Federation No. 075-00326-19-00 dated 27.12.2018.

\section{REFERENCES}

1. E. E. Jukova, I.Y. ilina, M. V. Gundarin, E. V. Potekhina, I. N. Misanova, A. I. Zotova, "Planning a New Business: Typical Mistakes of a Business Plan in the Service Sector", Journal of Environmental Management and Tourism,vol. 10(2), 2019, pp. 441-447.

2. G. I. Novolodskaya, E.Yu. Chicherova, L.A. Ponkratova, N. A. Gracheva, S. V. Ilkevich, "Investing in Human Capital in Tourism Companies",Journal of Environmental Management and Tourism, vol. 10(2), 2019,pp. 340-345.

3. V. Kataeva, T. Fomicheva, J.Sulyagina, J. Kuvshinova, T. Evstratova, G. Moskvitin, "Recommendation for the Use of Regional Tourist Resources by the Example of the Resort City of Sochi, Russia",Journal of Environmental Management and Tourism, vol. 10(1), 2019,pp. 244-251.

4. Iu. N. Minaev,"Analiz faktorov, vliyayushchikh na uroven sotsialno-ekonomicheskogo razvitiya regiona" [Analysis of factors influencing the level of regional socioeconomic development], Vestnik TGU [Tomsk State University Journal], vol. 1 (69), 2008, pp. 333-338.

5. N. V. Neveikina,"Faktory razvitiya regiona" [Regional development factors],Uchenye zapiski Orlovskogo gosudarstvennogo universiteta [Scientific Notes of Orel State University], vol. 1(57), 2014, pp.78-85.

6. V. Z. Petrosyants, S. V. Dokholyan,"Regionalnoe razvitie i faktory ekonomicheskogo rosta" [Regional development and economic growth factors],Regionalnaya ekonomika: teoriya i praktika [Regional Economy: Theory and Practice], vol. 18, 2007, pp. 10-17.

7. T.I. Bakinova, N. E. Darbakova, G. Ya. Kazakova, S. A. Sangadzhieva, I. E. Darbakova, "Information Support of Monitoring as a Tool of Ecological Optimization of Agricultural Land Use",Journal of Environmental Management and Tourism, [vol. 10(1), 2019, pp. 195-201.

8. E. M. Bukhvald, "Samorazvitie" regionov i prioritety regulirovaniya prostranstvennoi struktury rossiiskoi ekonomiki" [Regional self-development and regulatory priorities in spatial structure of the Russian economy],Federalizm [Federalism], vol. 2 (90), 2018, pp. 32-45.

9. I. S.Mezhov, I. N.Sycheva, E. S.Permyakova,"Samorazvitie regionov v kontekste mezhotraslevoi integratsii" [Regional self-development in the context of cross-industry integration],Ekonomika $i$ biznes: teoriya $i$ praktika [Economy and Business: Theory and Practice], vol. 10, 2016, pp. 119-124.

10. A. I.Tatarkin, D. A.Tatarkin,"Samorazvitie regionov v kontekste federativnykh otnoshenii" [Regional self-development in the context of federal relations],Prostranstvennaya ekonomika [Spatial Economics], vol. 4,2008, pp. 60-70.

11. V. S.Fedolyak,"Samorazvitie regionov kak sposob realizatsii ekonomicheskogo potentsiala" [Regional self-development as a method to realise economic potential],Izvestiya Saratovskogo universiteta. Novaya seriya. Ekonomika. Upravlenie. Pravo [Izvestiya of Saratov University. New Series. Series Economics. Management. Law], vol. 17(4),2017, pp. 428-433.

12. I. N.Shvetsova, T. A. Naidenova,"Kriterii opredeleniya sposobnosti regionov $\mathrm{k}$ samorazvitiyu (na materialakh severnykh subektov Rossiiskoi Federatsii)" [Regional self-development capacity criteria (as exemplified by the northern subjects of the Russian
Federation)],Sibirskaya finansovaya shkola [Siberian Financial School], vol. 1 (126), 2018, pp. 47-51.

13. H. S.Perloff, E. S.Dun, Jr., E. E.Lampard, R. F. Muth,Regions, Resources and Economic Growth, Lincoln, Nebraska: University of Nebraska Press, 1960.

14. K. Berzeg,"The Empirical Content of Shift-Share Analysis”,Journal of Regional Science, vol. 18, 1978, pp. 463-469.

15. H. J. Brown,"Shift-Share Projections of Regional Growth Empirical Test”, Journal of Regional Science, vol. 9, 1969, pp. 1-18.

16. J. M. Esteban-Marquillas, "A Reinterpretation of Shift-Share Analysis",Regional and Urban Economics, vol. 2, 1972, pp. 249-255.

17. C. F. Floyd,C. F. Sirmans, "Shift and Share Projections Revisited”, Journal of Regional Science, vol. 13,1973, pp. 115-120.

18. H. W. Herzog Jr., R. J. Olsen,"Shift-Share Analysis Revisited The Allocation Effect and the Stability of Regional Structure",Joumal of Regional Science, vol. 17, 1977, pp. 441-454.

19. D. B. Houston,"The Shift-Share Analysis of Regional Growth A Critique”,Southern Economic Journal, vol. 33, 1967, pp. 577-581.

20. F.James Jr.,J. Hughes,"A Test of Shift and Share Analysis as a Predictive Device”,Journal of Regional Science, vol. 13, 1973, pp. 223-231.

21. J. R. Lausen, "Venezuela: An Industrial Shift-Share Analysis, 1941-1961",Regional and Urban Economics, vol. 1, 1971, pp. 153-220.

22. H. Stevens Benjamin, L. Moore Craig,"A Critical Review Of The Literature On Shift-Share As a Forecasting Technique",Journal of Regional Science, Vol. 20, No. 4, 1980, pp. 419-437.

23. R.Zimmerman,"A Variant of the Shift and Share Projection Formulation”,Journal of Regional Science, vol. 15,1975, pp. 29-38.

24. Regiony Rossii. Sotsialno-ekonomicheskie pokazateli. 2018 [Regions of Russia. Socio-Economic Indicators. 2018]: Statistical book, Moscow, Rosstat. 2018.

\section{AUTHORS PROFILE}

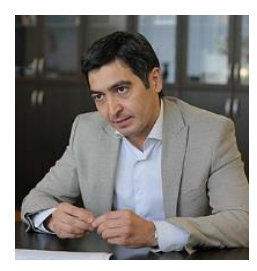

R.R. Akhunov, Doctor of Economics, Doctor of Business Administration.

The scientific and professional activities of Rustem Akhunov are related to issues of the regional economy. He is the developer of the Strategy for socio-economic development of the Republic of Bashkortostan for the period until 2030 in the part on the section on territorial development.

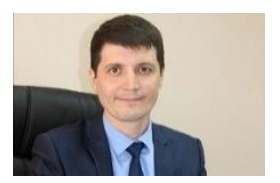

A.V. Yangirov, Doctor of Economics, Associate Professor.

Awards and honors:

1. Certificate of honor of the Administration of the city district of Neftekamsk (2009).

2. Excellence in Education of the Republic of

Bashkortostan (2010).

3. Certificate of honor of the Ministry of Education and Science of the Russian Federation (2013).

4. Four letters of appreciation from the Ministry of Education of the Republic of Bashkortostan (2014-2016). 